\title{
Spittle protein profile of Mahanarva spectabilis (Hemiptera: Cercopidae) fed various elephant grass genotypes
}

\author{
A.M. Auad ${ }^{1}$, M.F. Guimarães ${ }^{1}$, I. Fonseca ${ }^{1}$, S.V. Paula-Moraes ${ }^{2}$, \\ M.M. Kopp ${ }^{3}$ and M.C. Cordeiro ${ }^{2}$ \\ ${ }^{1}$ Embrapa Gado de Leite, Juiz de Fora, MG, Brasil \\ ${ }^{2}$ Embrapa Cerrados, Planaltina, DF, Brasil \\ ${ }^{3}$ Embrapa Pecuária Sul, RS, Brasil \\ Corresponding author: A.M. Auad \\ E-mail: amauad@cnpgl.embrapa.br
}

Genet. Mol. Res. 11 (4): 3601-3606 (2012)

Received January 18, 2012

Accepted July 17, 2012

Published October 4, 2012

DOI http://dx.doi.org/10.4238/2012.October.4.7

\begin{abstract}
An understanding of the interaction between spittlebugs and forage grasses is essential for establishing factors that favor productive pastures. In the present study, we evaluated the protein profiles of the spittle of Mahanarva spectabilis (Distant, 1909) (Hemiptera: Cercopidae) fed various elephant grass genotypes. Each plant was infested with a single fifth-instar M. spectabilis. After 24 $\mathrm{h}$, samples of the spittle produced by each nymph were collected and stored at $-20^{\circ} \mathrm{C}$, after which their protein profiles were analyzed. The exclusivity or interactions of the proteins present in the spittle produced by the insects revealed the susceptibility of the tested genotypes. The results indicate that groups of genotypes show identical spittle protein profiles when subjected to attack by spittlebugs. Resistant and susceptible elephant grass genotypes exhibited high similarity indices within each group. The similarity index was low for the resistance control species (Brachiaria brizantha) compared with that of the tested elephant grass
\end{abstract}


genotypes. Qualitative and quantitative studies of the proteins expressed in the most promising materials will be performed in an ongoing genetic improvement program seeking to develop genotypes resistant to spittlebugs, which are the main biotic pests of elephant grasses.

Key words: Plant resistance; Forage; Genetic improvement

\section{INTRODUCTION}

Elephant grass (Pennisetum purpureum Schum.) and signal grass (Brachiaria spp) are crucial forage species for the production of beef and milk in Brazil. However, the main limitation to the economic exploitation of these grasses for cattle grazing and fodder is attack by Mahanarva spectabilis (Hemiptera: Cercopidae), also known as spittlebug, which hinders the production of leaf mass. Chemical control of these pests in pastures is both uneconomical and anti-ecological owing to the large areas involved. Therefore, finding cultivars that are naturally resistant to spittlebugs through antibiosis is the most feasible strategy for their control (Valério et al., 1997; Miles et al., 2006; Auad et al., 2007; Sotelo et al., 2008; Souza Sobrinho et al., 2010). Studies aimed at discovering resistant cultivars are relatively time-consuming. In addition, they can lead to a breakdown of resistance if they are not monitored properly. Therefore, a thorough understanding of the interaction between the pest and the plant is important for re-establishing the favorable factors required for plant production.

The genetic diversity of the elephant grass germplasm bank of the Embrapa Dairy Cattle Research Unit can reveal the factors influencing the specificity of the spittlebugs for this forage grass. Spittlebugs get their name from the mass of foam called spittle or spume with which they surround themselves during the immature phase. In addition to providing a moist environment, this foam also protects the insects against predators. The nymphs excrete a liquid produced from the sap of the plant to which they add air bubbles created by expanding and contracting their abdomens while mixing in secretions from structures such as the Batelli glands and Malpighi tubes (Kato, 1958; Marshall, 1965); these secretions are important for stabilizing the foam (Valério, 2009).

Analyzing the protein profiles of the spittle of insects fed various elephant grass genotypes is hypothesized to reveal the groups of proteins involved in resistance to their attack. Such knowledge would inform genetic improvement programs by enabling the selection of resistant materials through an understanding of the mechanisms involved in the host-pest interaction. However, studies on this topic remain in early stages. The objective of the present study was to evaluate the spittle protein profile of spittlebugs fed various elephant grass genotypes.

\section{MATERIAL AND METHODS}

Spittle samples of $M$. spectabilis specimens raised on various $P$. purpureum genotypes were collected and analyzed. Two signal grass cultivars, Brachiaria ruziziensis and B. brizantha, were included as controls for susceptibility and insect resistance, respectively (Valério et al., 1997; Cardona et al., 2004). Each plant was infested with one-fifth instar. After 24 h, the spittle was collected with a scoop, placed in a microtube, and stored at $-20^{\circ} \mathrm{C}$. The protein profiles in the macerated material from $M$. spectabilis nymphs were evaluated and compared to one another. 
The protein profiles of the spittle were determined using an Agilent 2100 Bioanalyzer (Agilent Technologies Inc., Wilmington, DE, USA) and a Protein 230 LabChip Kit (Agilent) according to manufacturer recommendations. Each spittle sample was centrifuged at $1500 \mathrm{~g}$, and $4 \mu \mathrm{L}$ supernatant was mixed with $2 \mu \mathrm{L}$ denaturing solution (supplied with the kit) containing 35 $\mathrm{mM}$ dithiothreitol. The samples were denatured for $5 \mathrm{~min}$ at $100^{\circ} \mathrm{C}$, incubated on ice for $1 \mathrm{~min}$, and diluted with $84 \mu \mathrm{L}$ water. Then, $6 \mu \mathrm{L}$ of each diluted sample was applied to a chip. The Protein 230 LabChip Kit permits separation within the range of 14-230 kDa. A molecular weight marker was applied to each chip to determine the protein profile of the spittle samples. The molecular weights were analyzed, and the proteins were quantified using the 2100 Expert software (Agilent).

The proteins in the samples were classified as present (1) or absent (0). A matrix was constructed to calculate the similarity between all genotype pairs based on the protein profiles obtained from the spittle produced by the nymphs raised on each genotype with the aid of the NTSYS pc 2.1 computational program (Rohlf, 2000). The simple matching coefficient (Sokal and Michener, 1958) was used to calculate similarity $\left(S_{i j}\right)$ according to the following equation: $S_{i j}=a$ $+d / a+b+c+d$, where $a$ is the number of binary characters (or markers) for which both samples had code 1 (presence), $b$ is the number of 0 codes for sample $i$ and 1 codes for sample $j, c$ is the number of 1 codes for sample $i$ and 0 codes for sample $j, d$ is the number of marks for which both samples had code 0 (absence), and $a+b+c+d$ is the total number of marks studied. The number of coincidences is represented by $a+d$, and the number of differences by $b+c$. A dendrogram was constructed based on the similarity matrix using the unweighted pair group method with arithmetic mean. To verify the fit between the dissimilarity matrix and the dendrograms, the cophenetic correlation coefficient (r) was calculated according to the method of Sokal and Rohlf (1962).

\section{RESULTS AND DISCUSSION}

High variability was found in the expression of proteins with molecular weights ranging from 15 to $209 \mathrm{kDa}$ in the spittle samples from M. spectabilis nymphs fed various elephant grass genotypes (Table 1). All of the spittle samples formed from the sap extracted from the tested elephant grass genotypes expressed a protein with a molecular weight between 53 and $57 \mathrm{kDa}$ except for those from nymphs fed the King Grass, CNPGL 94496, P241 Piracicaba, Sem Pêlo, and Roxo de Botucatu genotypes and the resistant control species, B. brizantha (see Table 1). The exclusivity of this protein in the spume was demonstrated when the Napier, Gaçu, Cameroon, Taiwan 144, Taiwan, Paraíso, Kizozi, Common Mercker, Empasc 307, Empasc 306, Mercker 23A, Vrukwona, Porto Rico, Mott, and Santa Rita genotypes were offered to the nymphs (see Table 1). According to the resistance evaluation criterion of Auad et al. (2007), these genotypes are susceptible to M. spectabilis; the survival of nymphs ranged from 55 to $92 \%$ except for the Santa Rita genotype, which was not in the susceptible cluster. Therefore, the exclusivity of this protein represents a potential expression marker of this characteristic in elephant grasses.

The interactions between the various proteins present in the spittle of the nymphs fed plants of various genotypes are also critical to consider. The joint presence of proteins with molecular weights of 19-21 kDa and those of 53-57 kDa was an exclusive feature of the spittle samples from the nymphs fed the Cameroon de Piracicaba, Pioneiro, CNPGL 96273, and Cuba genotypes (see Table 1). These genotypes are considered the most promising for their negative effect on the survival of M. spectabilis (Auad et al., 2007). Furthermore, the presence of this protein cluster in these genotypes is an indication that these materials confer resistance to spittlebugs. 
A.M. Auad et al.

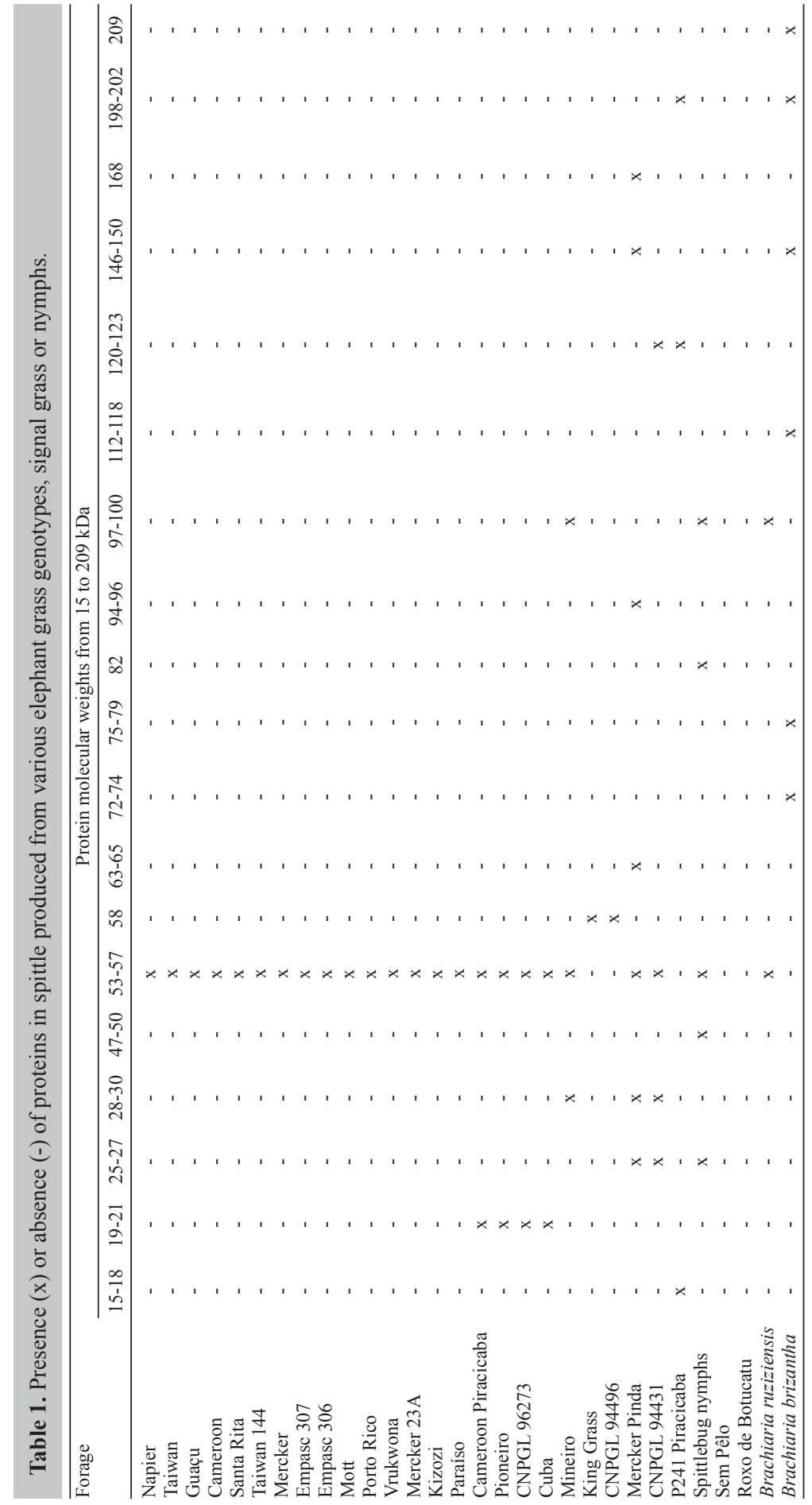


Proteins with these molecular weights along with those with weights of 97-100 kDa were detected in the spittle produced by nymphs fed the Mineiro cultivar, which is characterized as highly susceptible. This result indicates that the relationships between proteins within this molecular weight range can help determine the susceptibility of genotypes. Notably, the spittle produced by nymphs fed $B$. brizantha (the control species for spittlebug resistance) contained the largest number of protein types and those with the highest molecular weights, including proteins of 72-74, 75-79, 112-118, 146-150, 198-202, and $209 \mathrm{kDa}$ (see Table 1), which were exclusive to this spittle. This finding corroborates that of Rossignol et al. (2006), who have reported that more proteins are expressed by resistant rather than susceptible genotypes. Furthermore, they have reported that these proteins are associated with the defense or secondary metabolism of the plants.

The absence of proteins with molecular weights between 15 and $209 \mathrm{kDa}$ or the exclusivity of those with a weight of $58 \mathrm{kDa}$ was detected in the Roxo de Botucatu and Sem Pêlo or King Grass and CNPGL 94496 genotypes, respectively; these are characterized as susceptible to attack, with nymph survival greater than $80 \%$ (Auad et al., 2007).

The genotypes evaluated were very similar, as indicated by few differences detected in the expression of proteins between 15 and $209 \mathrm{kDa}$. Although small, these differences in protein expression can be sufficient to characterize the mechanism(s) of stress resistance (Figure 1). Clusters of genotypes produced identical protein profiles when subjected to spittlebug attack. High similarity $(96 \%)$ also occurred between resistant and susceptible elephant grass genotypes. These profiles were similar to that of $B$. ruziziensis (susceptibility control), which contained proteins with weights of 53-57 and 97-100 $\mathrm{kDa}$. All tested materials exhibited low similarity with the signal grass species used as the resistance control (B. brizantha; Figure 1). The high cophenetic correlation coefficient obtained in this analysis $(r=0.9647)$ allows us to conclude that the constructed dendrogram (see Figure 1) closely represents the real distances between each genotype pair.

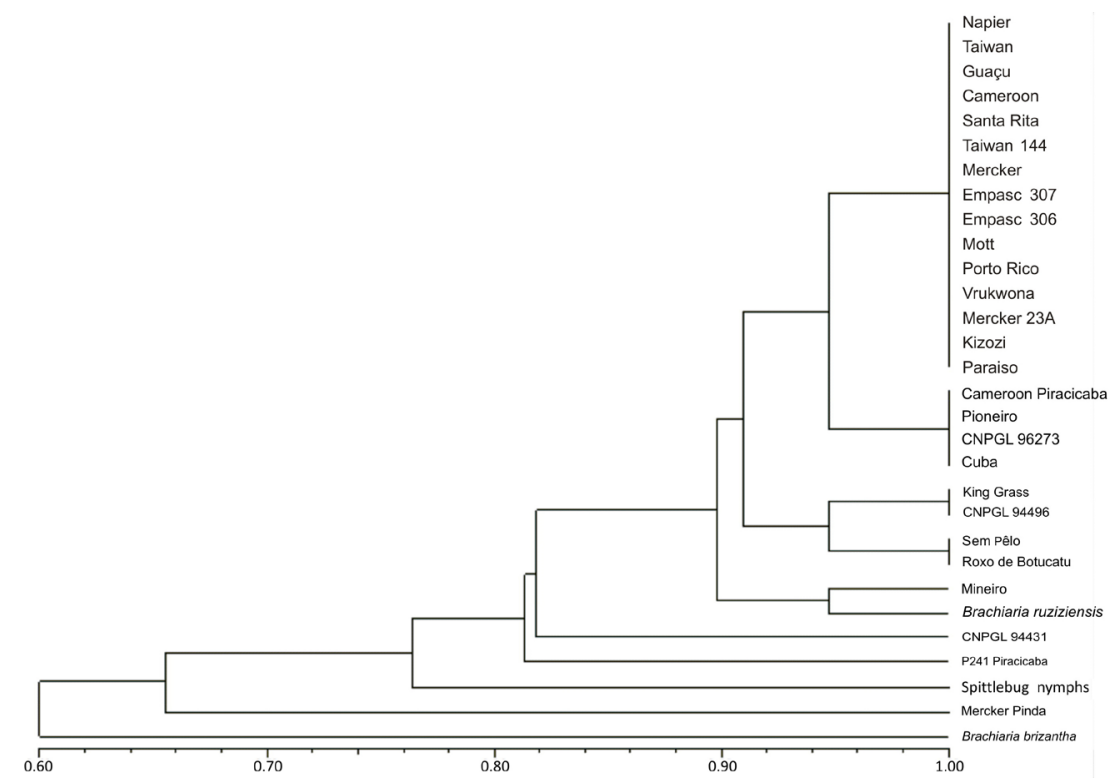

Figure 1. Dissimilarities (mean genetic distances) between the elephant grass genotypes and signal grass species submitted to spittlebug attack. $r=0.96268$. 
The P241 Piracicaba, CNPGL 94431, and Mercker Pinda genotypes exhibited different protein profiles, leading to lower similarity levels compared with those of the other elephant grass genotypes. Likewise, distinct protein profiles were found in the macerated material from M. spectabilis nymphs compared with the spittle from the other tested materials, suggesting that the proteins contained in the spittle samples match those extracted from the various genotypes (see Table 1 and Figure 1).

Two considerations must be made when interpreting these results. First, the resistance mechanism (by means of antibiosis) of a specific genotype is in many cases associated with differences in the expression of only one or a few genes because of structural modifications in one or a few proteins. Second, the variations observed in the protein profiles in this study are related to complex insect-plant interactions. Resistant plants may induce the expressions of the various proteins measured in the spittle produced by the insects.

Thus, the results indicate that interactions result in the expression of proteins with different molecular weights with respect to the various forage grass genotypes offered to the nymphs.

\section{ACKNOWLEDGMENTS}

Research supported by Fundação de Amparo à Pesquisa do Estado de Minas Gerais and Conselho Nacional de Pesquisa.

\section{REFERENCES}

Auad AM, Simões AD, Pereira AV, Braga ALF, et al. (2007). Seleção de genótipos de capim-elefante quanto à resistência à cigarrinha-das-pastagens. Pesq. Agropec. Bras. 42: 1077-1081.

Cardona C, Miles JW and Sotelo G (1999). An Improved Methodology for massive screening of Brachiaria spp. Genotypes for resistance to Aeneolamia varia (Homoptera: Cercopidae). J. Econ. Entomol. 92: 490-496.

Cardona C, Fory P, Sotelo G, Pabon A, et al. (2004). Antibiosis and tolerance to five species of spittlebug (Homoptera: Cercopidae) in Brachiaria spp.: implications for breeding for resistance. J. Econ. Entomol. 97: 635-645.

Kato K (1958). Origin and composition of spittle made by spittlebugs. Sci. Rep. Saitama Univ. Ser. B. 3: 33-53.

Marshall AT (1965). Batelli glands of cercopoid nymphs (Homoptera). Nature 205: 925.

Miles JW, Cardona C and Sotelo G (2006). Recurrent selection in a synthetic brachiariagrass population improves resistance to three spittlebug species. Crop Sci. 46: 1088-1093.

Rohlf FJ (2000). NTSYSpc: Numerical Taxonomy and Multivariate Analysis System. Version 2.1. Exeter Software, New York.

Rossignol M, Peltier JB, Mock HP, Matros A, et al. (2006). Plant proteome analysis: a 2004-2006 update. Proteomics 6: 5529-5548.

Sokal RR and Michener C (1958). A statistical method for evaluating systematic relationships. Univ. Kansas Sci. Bull. 38: 1409-1438.

Sokal RR and Rohlf FJ (1962). The comparison of dendrograms by objective methods. Taxon 11: 30-40.

Sotelo PA, Miller MF, Cardona C, Miles JW, et al. (2008). Sublethal effects of antibiosis resistance on the reproductive biology of two spittlebug (Hemiptera: Cercopidae) species affecting Brachiaria spp. J. Econ. Entomol. 101: 564-568.

Souza Sobrinho F, Auad AM and Lédo FJS (2010). Genetic variability in Brachiaria ruziziensis for resistance to spittlebugs. Crop Breed. Appl. Biotechnol. 10: 83-88.

Valério JR (2009). Cigarrinhas-das-pastagens. Vol.1. Embrapa Gado de Corte, Campo Grade.

Valério JR, Jeller H and Peixer J (1997). Seleção de introduções do gênero Brachiaria (Griseb) resistentes à cigarrinha Zulia entreriana (Berg) (Homoptera: Cercopidae). An. Soc. Entomol. Bras. 2: 383-387. 